Studia nad Autorytaryzmem i Totalitaryzmem 43, nr 3 Wrocław 2021

https://doi.org/10.19195/2300-7249.43.3.14

\author{
KAMILA ZARYCHTA-ROMANOWSKA \\ ORCID: 0000-0002-8403-0156 \\ Uniwersytet Wrocławski \\ zarychta@gmail.com \\ MACIEJ SZOSTAK \\ ORCID: 0000-0002-9880-0529 \\ Uniwersytet Wrocławski \\ maciej.szostak@uwr.edu.pl
}

\title{
Women and their rights: From totalitarianism to feminist empowerment in the context of the 20th anniversary of UN1325 on women, peace, and security between victims, leaders, and perpetrators
}

\begin{abstract}
While analysing the heritage, input, and various implementation contexts of UNSCR 1325 on women, peace, and security, the authors investigate not only various approaches to women's position and female empowerment in international engagement settings and cooperation models (UN, OSCE NATO, UNCDF), but also look at female empowerment in a global scope from women's perspectives as victims, leaders, and perpetrators. By considering the need for complex engagement of international actors in stability, development, and crisis initiatives, the authors analyse NATO policy against sexual abuse and exploitation, on women's financial inclusion, and the MenEngage initiative. While analysing the societal impact of radicalisation, they seek answers for effective reintegration and anti-radicalisation of female terrorists and foreign fighters. Authors examine the evolving gender equity and female empowerment policies of the EU in their foreign and domestic affairs, with particular interest in internal and external security standards for women's safety.
\end{abstract}

Keywords: women, peace, and security, WPS, stability policing, women, security, OSCE, UN Women, NATO, UNCDF, radicalisation, foreign fighters, peacebuilding, EU, UNSCR 132, gender policies, counter radicalisation, gender based violence, international policing. 


\section{UN1325 Resolution - the core commitments ${ }^{1}$}

As was rightly observed by the Secretary-General on women, peace, and security: "Inclusion of women in peace processes and peace talks leads to a more sustainable peace. Women bring new dynamics and perspectives that will enhance implementation of peace agreements."

Certainly, there is a need to regulate the rights of women living in different geographic zones, cultures, diverse worldviews, etc. On the 20th anniversary of this Resolution, a reference will be made to the idea its creators had as regards its functioning and importance in relation to women's rights. As it is relatively easy to state in the areas within the European law or the global culture of the North, the issues of the statute and women's rights in relation to the countries as well as cultural and religious areas in which their status remains unequal, still remain valid. It is, therefore, worthwhile - without referring to specific events that inspired the creators of the Resolution, such as the wars in Africa and the Balkans - to look at the Resolution through its effectiveness and highlight those legislative areas that seem relevant and require legislative interference.

The world and the spectrum of international organisations together with various stakeholders and NGOs are marking the 20th anniversary of gender equity in war and totalitarian settings milestone adopted on 31 October 2000 by the United Nations Security Council - Resolution 1325 on women, peace, and security (commonly known as UN SCR 1325 or WPS Resolution). ${ }^{3}$

This event inspired us to assess the impact of the first UN legislation to recognize that armed conflict affects women and men differently and calls for the meaningful participation of women in peace processes, as well compares women's engagement in war and security process after the Second World War.

The \#WomenPeaceandSecurity1325 is the one of most translated UN Resolutions ever, ${ }^{4}$ which comes as a surprise, bearing in mind that female rights are still globally sacrificed for the sake of the greater good or regional stability, while preserving totalitarian or autocratic status quos, based on denying women participation in public life. The ambitions of the Resolution are to reaffirm the important role of women in preventing and resolving conflicts, negotiating peace, peacebuilding, peacekeeping, humanitarian response, and post-conflict reconstruction. Moreover, it stresses the importance of their equal participation and full involvement in all efforts for the maintenance and promotion of peace and security, while

${ }^{1}$ UN Security Council, Resolution 1325, Women and peace and security, 2000, http://unscr. com/en/resolutions/1325.

2 Report of the Secretary-General on women and peace and security (S/2015/716), https:// reliefweb.int/report/world/report-secretary-general-women-and-peace-and-security-s2015716.

3 UN Security Council, Resolution 1325.

${ }^{4}$ PeaceWomen, Resolution Texts and Translations, https://www.peacewomen.org/resolutionstexts-and-translations (accessed: 5.12.2020). 
calling all actors to increase the participation of women and incorporate gender perspectives in all United Nations peace and security efforts.

The reaffirmation of those values and urging all parties of conflicts to preserve them and take special measures to protect women and girls from genderbased violence, particularly rape and other forms of sexual abuse, in situations of armed conflict, is unfortunately, 20 years later, only an international humanitarian dream. The tragic situation of Yazidi women, girls being kidnapped by Boko Haram, highlights the victimisation of women in conflict and lacerates the very essence of society.

The emerged terrorist autocracy and their religion based totalitarian regimes were addressed by the UNSCR 2242 Resolution which emphasizes the different impact on the "human rights of women and girls of terrorism and violent extremism, including in the context of their health, education, and participation in public life," and also points out that "they are often directly targeted by terrorist groups." 5 The phenomenon of the totalitarian Islamic State was described already in UNSCR 2178 on foreign terrorist fighters, ${ }^{6}$ which seeks to engage member states in relevant local communities and non-governmental actors in countering violent extremism, including by empowering women and other concerned civil society groups. ${ }^{7}$ At the same time, 2017 UNSCR 2396 also encourages member states to ensure the leadership and participation of women in designing, implementing, monitoring, and evaluating strategies aimed at addressing the fate of returning and relocating foreign terrorist fighters (FTF) and their families, ${ }^{8}$ bearing in mind mostly aggressive masculism and male reintegration.

The UN's ambitious goals for women shall lead to proportionate funding and gender-balanced staffing in the peacebuilding and stabilisation mission, and to maintain the financial and economical integrity women desperately need. Observed "economical/social independence" resulted in surviving instincts leading to women taking over the main breadwinner role in the conflict- or war-torn societies, especially in the least developed countries (LDC), when the traditional family organisation setting is often used as a tool to economically and culturally exclude women from all levels. The presence of female peacebuilders and their support from female parts of society is addressing the most comprehensive way of implementing "gender ideology and female empowerment" at the UN field missions of peacebuilding and social restoration.

${ }^{5}$ UN Security Council, Resolution 2242, Women and peace and security, 2015, http://unscr. com/en/resolutions/2242.

${ }^{6}$ UN Security Council, Resolution 2178, Threats to international peace and security caused by terrorist acts, 2014, http://unscr.com/en/resolutions/2178.

${ }^{7}$ Fact Sheet: UN Security Council Resolution 2178 on Foreign Terrorist Fighters, https:// www.justice.gov/file/344501/download.

${ }^{8}$ UN Security Council, Resolution 2396, Threats to international peace and security caused by terrorist acts, 2017, http://unscr.com/en/resolutions/2396. 


\section{From victims to peace leaders}

Certainly, while analysing the acquis of the United Nations Security Council Resolution (UNSCR) 1325 and its follow-up Resolutions, we shall regard it as one of the most important global instruments for fostering women and gender issues in security and defence. Not only to seek and see justice for women, but also to address and support them judicially via dedicated female law enforcement officers. The said Resolution identifies women as important actors in peacebuilding and conflict mediation as well as sets standards to restore the universal nature of the Universal Declaration of Human Rights. ${ }^{9}$ The projected goals of women's increased involvement at all-decision-making levels - in conflict prevention, crisis management, and post-conflict reconstruction — set a long-term plan, which has to be updated to respond to the current threats and long-lasting genderand culture-based violence against women. ${ }^{10}$

The most crucial aims of the Resolution are to systematically incorporate gender considerations into peace and security matters, to actively involve women, and to integrate gender perspectives into national and multilateral security initiatives. This requires an updated approach and long-term involvement of all stakeholders as well as the public. Looking at the historic context of complex victimisation of women by various autocratic governments, we will come to the realisation that throughout history, women were predominantly victims of sexual violence, slavery, or forced silent witnesses of atrocities, serving various conflict parties as servants or home support. While observing female engagement in both the Second World War and during the East-West conflict, we have to come to a very sad conclusion of the prominent tendency to use sexual abuse and rape as a weapon in certain conflicts. Twenty years after the UNSCR 1325, we can observe the enslavement, forced marriages, and encroachment on women and girls' rights to education and participation in public life on the territories controlled by violent extremist and/or terrorist groups. They target mostly women, who are often attacked, abused, abducted, tortured, displaced, sold, enslaved, and murdered.

\section{The full spectrum of war and gender-based violence}

It seems that women's support was finally addressed by UN Women through a set of various initiatives to support their access to healthcare providers, secure their safety, and confirm their human rights in humanitarian crisis settings. With

${ }^{9}$ Universal Declaration of Human Rights, https://www.un.org/en/about-us/universal-declara tion-of-human-rights.

${ }^{10}$ More broadly in the contexts of: the theory of research on freedom of religion and conscience, as well as psychonipulation and psychological violence: M. Szostak, Desputable Religious Movements and Public Security, London 2013; idem, Sekty destrukcyjne. Studium metodologiczno-kryminalistyczne, Kraków 2001. 
inclusive peace settlements and peace missions, reintegration programmes, as well as disarmament and demobilization missions, the women involvement proves to deliver long-lasting changes and bridge-building solutions when incorporating a gender-positive approach into all actions and activities performed by the UN police. Therefore, the actions to achieve a full gender and social representation at strategic, operational, and tactical levels shall include strong representation of women and youth, as their needs have to be thoroughly assessed and the consequences for those groups should be considered in all undertakings.

In this particularly difficult time of a global pandemic, in conflict or crisis spheres, the female engagement became even more crucial. While women were already commonly performing tasks that had earlier been perceived as male and managing societal undertakings such as heading households or supporting communities, new pandemic-related health and hygiene tasks arise on the health emergency frontline.

While post-conflict settings tend to create a particular window of opportunity to build on women's enhanced participation in decision-making and peacebuilding settings, the host countries and particularly law enforcement authority can and shall, supported by the international community, enhance the recruitment of female officers. Still, we can globally observe an ephemeral, to put it mildly, appreciation of women's role in bringing and promoting international peace and security, acknowledging their spaces in various spheres of influence, and appreciating their outstanding efforts in making a difference. Otherwise we are on the brink of losing another generation of women and girls, enslaved by conflicts, crisis, and war.

The importance of universal engagement of United Nations peacekeeping or more and more female-oriented NATO stability policing is raising, as the threats of various origin hit hard the region on crisis leading to a serious deterioration of women and girls' situation.

The human rights of women, their right to be heard and to decide on their future, has to be expressed as well when it comes to the composition of peace tables and a comprehensive approach in the appropriate mechanism of participation and influence of all parties.

It is 20 years after UNSCR 1325 and there is no room for denying the need for women's public participation and their role as actors of change in terms of stability, peace, and development.

UN police officers, as peacekeepers, must promote and protect human rights, protect children from violence, including from illegal recruitment into armed forces as child soldiers (S/RES/1612 (2005)), promote gender equality, involve women in peace and security activities, protect women and children from sexual violence in conflict (S/RES/1325 (2000)) and (S/RES/1820(2008)), and contribute to create an environment where human rights are respected. ${ }^{11}$

11 Stability Policing: A Tool to Project Stability, eds. V. Stingo, M. Dziedzic, B. Barbu, Norfolk, VA 2000, https://www.act.nato.int/images/stories/media/doclibrary/stability_policing.pdf. 
Indeed, it is of primordial importance to reflect on women and youth's needs and visions in order to not only secure ceasefire, but also participate in peacebuilding, stability policing, and reconstruction in the regions affected. Particularly, female leadership proves to be a solution at the pandemic frontline, while mitigating the political and security risks that arise. These risks can significantly jeopardize the milestone achievements for women's participation in peace and political processes as well as implicate drastic gender-based violence in family and lockdown settlements, worsening vulnerability of women and girls to poverty as well as sexual and gender-based violence. ${ }^{12}$

The humanitarian crisis, pandemic, or conflict incitement threatens the very existence of women's human rights and sustainable peace. Hence, it requires a systemic response which will ensure women's equal and meaningful participation in all peace and security areas as well as in the decision-making process to prevent and fight not only Ebola, Zika, COVID-19, swine flu, or the malaria crises, but also all humanitarian emergencies through a range of both tailormade and universal political, preventive, and mitigation measures.

It is not a truism to highlight that no sustainable peace can be achieved while women's voices and perspectives are being ignored. The positive engagement approach in the creation of long-terms solutions in the regional support, with relevant support of stabilisation policy missions, as well as by economic and financial support and entrepreneurship, i.e. via last mile financing as foreseen in, ambitious digital inclusion programs with micro credits and microfinancing mechanism, were provided by UNCDF and supported by UE development initiatives, as an economic stability tool.

In the era of violent extremism, religious radicalisation, and permanent threat to women's existence and freedom in certain regions, the Women, Peace and Security Agenda has to be reinforced by comprehensive policing solutions, especially when it comes to domestic, intimate partner, and structural violence of various kinds. Several initiatives promote women's rights and equity: UN women empowerment programs and OSCE-inspired MenEngage, all needed for transparent support for sexual abuse and exploitation tantrum. ${ }^{13}$ MenEngage seeks to raise general awareness on the influence men can have on ending gender-based violence and speaking out against all kinds of inequality through campaigns, engaging boys and men to advance gender equality and to promote positive role models for men and boys in non-war environment. However, accomplishing these tasks can be impossible in warzones.

12 Compare in the context of violation of sexual freedom and integrity: K. Grott, M. Szostak, Incest Criminological Studies, Poznań 2013.

13 OSCE, OSCE Men for Gender Equality, https://www.osce.org/secretariat/menengage. 
This can be amended by adopting the 2020 NATO policy on preventing and responding to sexual exploitation and abuse. ${ }^{14}$ Stability and peacebuilding missions required this innovative policy tool of high external and internal importance to adopt NATO's stability goals to contemporary conflict needs and universal obligations. By defining sexual exploitation ${ }^{15}$ and abuse, ${ }^{16}$ as well as creating prevention and prohibition mechanisms, NATO set a very comprehensive example and set of rules, which shall be implanted in every stability, peacebuilding, or crisis management operation handled by international actors. The absolute requirement of pre-deployment mandatory training on preventing and responding to sexual exploitation and abuse, combined with identification of risk factors and ensuring appropriate mitigation, will lead to personnel engagement to prevent and respond to sexual exploitation and abuse within their sanctioned power and authority.

By those provisions and global efforts, the importance of women's engagement in the area described in Resolution 1325 gender-responsive arms control and disarmament measures sets out best practices and areas for further action. Further integration of WPS and gender equality requires more than a throughout approach: full participation of policy actors and practitioners, engaging with arms control and disarmament help to operationalize the WPS agenda. To keep the WPS real and operational in a long-term perspective, women's economic and financial inclusion is absolutely necessary alongside their personal security and strengthening.

\section{UN Women — global achievement?}

Certainly, it is difficult to anticipate the imperceptible changes in the global aspiration to ensure the appropriate female empowerment, but the opportunities which arise in the rapidly changing global environment require sustained efforts.

We can observe that women who took the lead whilst ensuring the wellbeing and the very existence of their families do not hesitate to change the course and explore new horizons. This certainly is the case as well with de-radicalisation activities when accommodating the returning extremists. Changing a peace and security perception, turning the emphasis from fight to development and support is therefore often associated with the idea of permanent change and social evolution. Despite women's extraordinary strength and importance in the time of crises

14 NATO, Policy on preventing and responding to sexual exploitation and abuse, 20.11.2019, https://www.nato.int/cps/en/natohq/official_texts_173038.htm (accessed: 5.12.2020).

15 Is any actual or attempted abuse of a position of vulnerability, differential power, or trust, for sexual purposes, including, but not limited to, profiting monetarily, socially or politically from the sexual exploitation of another, including sexual services and any kind of exploited behaviour.

${ }^{16}$ Is any actual or threatened physical intrusion of a sexual nature, whether by force or under unequal or coercive conditions. Especially with persons under the age of 18 . 
highlights importance of full inclusion in decision making process. Sometimes, way too often, various stakeholders tend to overlook the necessity of keeping a full spectrum of society, whilst routinely keeping "traditional" status quo.

The emergence from a personal growth period will evidently lead towards more comprehensive awareness and strengthening women's motivation to reach social and economic goals as a consequence of recovery from their traumas. It is essential to separate superfluous short-term goals from the essential ones and focus on actions which are likely to bring real social contentment, and therefore development, stability, and peace. This natural benevolence allows women to maintain cordial relations with the society as well as become agents of change. The association of female empowerment with financial inclusion will lead to greater social cohesion and indicates that the need for a new horizon can be satisfied in a comprehensive way only by achieving all sustainable development goals as well as providing stability and safety on a personal level, without counterbalancing it with short-term solutions of adverse effects.

The idea of change is therefore linked to most deeply rooted certainties and social schemas which force women into a submissive role. The global UN peacekeeping engagement is taking necessary steps to improve global security and safety of women endangered by hybrid threats and victimisation. In a highly idealistic and individualistic world, women's empowerment should be seen as an announcement of a period of peace and prosperity both in the region of conflict and in the global north. If we regarded and channelled the UNCDF efforts for financial inclusion towards female empowerment in LDCs, we could possibly create a break in the social constrains and allow society to permanently leave the men-only zones while pushing along a strong wind of change that will help to overcome the crisis- or war-related injuries and economic or societal obstacles faster than expected. The financial inclusion influence can become particularly conspicuous in the family, domestic, and political spheres, and can perhaps deliver unexpected economic growth, employment, and social stability while contributing to rule of law and social inclusion.

The achievement of long-term goals needs involvement of will, choice, and stability to be assured. Not only self-confidence and the desire to move forward in order to seize the great professional opportunities, but also, first and foremost, financial independence and inclusion, social support, and safety - these are the key elements to achieve the sustainable development goals (SDG) and eradicate gender-based violence and use of sexual abuse as war tactics.

The goals and heritage of UNSCR on women, peace, and security shall be included in every project in LDCs in order to truly achieve long-term result and accomplish development projects. The affirmative answer for global peace is the full application of WPS Resolutions and careful, inclusive civil-military cooperation in peacebuilding, stability policing, and effective implementation 
of a comprehensive cooperation platform to reduce irregular migration, ${ }^{17}$ human trafficking, and hybrid threats (with the applaudable examples of NATO stability policing preparation through its Stability Policing Centre of Excellence, UNODC initiatives in the context of global response to crime, and IOM's global compacts on migration and asylum).

\section{Women as perpetrators}

Although at first sight it seems counterintuitive to associate the notions of women's empowerment and radicalisation, it is worth to analyse the lack of appropriate women empowerment and long-lasting conflict-related threats in the context of their susceptibility to radicalisation.

While we can globally observe the growth of counter-extremism initiatives, it seems as if they are predominantly designed to address radicalised men via engaging women as a part of their rehabilitation process. Regardless whether the woman is a mother, a wife, a partner, or a sibling — the female role is deemed as a "field worker of resocialisation at home". The terrorist recruitment process is rightly perceived as an entanglement process, usually with serious inclinations to exploit serious existing objective grievances present in a society and based on identifying members' highly personal vulnerabilities related to exclusion as well as psychological, emotional, or social contexts. The idea of countering the appeal of violent rhetoric not only hinders a long-term peacebuilding approach, but also - while seeking to create a tightly knit community — is a threat to the very existence of women. Consistently, a tiny shift in how the women's role is perceived is enough to change the settings drastically. Certainly, more coherent communities could be more resilient to harmful influences; unfortunately, they can also be more prone to it.

The importance of full compliance with human rights obligations when fighting terrorism, reaffirmed in UNSCR $2178^{18}$ and supported by the argument that a failure to do so contributes to radicalization, puzzles us with a question whose human rights? The returning foreign terrorist fighters'? ${ }^{19}$ Other members

17 M. Szostak, B. Wiśniewska Paź, K. Zarychta-Romanowska, “Globalizacja nieregularnej migracji rozważania o wpływie międzynarodowego kryzysu migracyjnego i jego implikacjach", Transformacje XII, 2019; eidem, "Krymigracja, kryminalizacja migracji a abolicja nieregularnej migracji”, Studia Sociologica 2, 2019, no. 11, pp. 63-74.

18 UN Security Council, Resolution 2178.

19 K. Zarychta-Romanowska, "European border and coast guards agency: Irregular migration management and creation and application of EU immigration law", Revista Facultatii de Drept Oradea 2018, no. 1 (on foreign fighters in the irregular migration and security concerns context); M. Szostak, Desputable Religious Movements... and idem, "Cults in Europe as a controversial social, legal and scientific problem", [in:] Controversial Cults: Various Approaches, Poznań 2013 (on religious radicalisation). 
of the receiving community - especially abandoned families'? Why women and children often seem to have an obligation to accept returned extremists with the baggage of post-war traumas, irregular migration journey, and criminal or war crime stigmas?

We can observe that when drafting projects and plans on peace, stability, or post-crisis policing, it can be observed that almost exclusive attention is being given to aggrieved members of the community by providing them support with non-violent means of expression or positive alternative methods to channel expectations. The role of women tends to be disregarded or used to achieve policing plans. The community's social tissue could resist damage, allowing them to bounce back, but will return to the violent solution which undermines not only human rights and the potential of women, but also their existence. How comprehensive are "considerable efforts" of the international community and local actors in affected communities if - while defining the threat of violent extremism and creating conceptual settings foundations to implementation, monitoring, and evaluation methods to counter extremism - they exclude the female decision-making participation? Is the ultimate goal of global counter-extremism aligned with the advancement of women's equity while making the vulnerable communities more resilient to violent extremism? ${ }^{20}$ The long-term abuse, denial of any form of freedom and human rights, and the various traumas, but also - paradoxically - female empowerment and serious shift in global perception of women role in global politics, lead to a serious shift in the global perception of women's role in global politics and society. The definition of foreign terrorist fighters, "individuals who travel to a state other than their states of residence or nationality for the purpose of the perpetration, planning, or preparation of, or participation in, terrorist acts or the providing or receiving of terrorist training, including in connection with armed conflict," 21 does not mention their gender.

While setting the UN Global Counter-Terrorism Strategy, ${ }^{22}$ the strong indication of the need to re-energize the UN prevention agenda - especially with respect to preventing armed conflict, atrocities, disasters, violence against women and children, and conflict-related sexual violence, as well implementing the Women, Peace and Security Agenda - highlights the importance of understanding in the most comprehensive way the lessons already learned to refine global actions and rendering them more effective when considering the most effective counter-radicalization tactics.

It seems, unfortunately, that the idea of "women as perpetrators" seems unbearable in the context of war crimes and terrorism to many, which eventually

${ }^{20}$ Radicalisation Awareness Network, European Commission, https://ec.europa.eu/home-af fairs/what-we-do/networks/radicalisation_awareness_network_en.

21 UN Security Council, Resolution 2178.

22 UN General Assembly, Plan of Action to Prevent Violent Extremism. Report of the SecretaryGeneral, https://www.un.org/en/ga/search/view_doc.asp?symbol=a/70/674. 
leads to refusing a female-oriented effective rehabilitation as well as counter-extremism measures and support. While observing the beginning of new terrorists strategies for increasing the role of women in jihadist and terrorist movements being applied, we can see as well the unexpected role of female foreign fighters in contemporary conflicts. ${ }^{23}$ The urgent need to intensify efforts within criminology/police-science and civil-military cooperation in gender-sensitive terrorism and extremism research, reinforced with extensive data collection on women's roles in violent extremism, stabilisation policing, and conflict, has to be addressed without delay.

While exploring and identifying the conglomerate of drivers that lead women to join violent extremist groups, scholars took into account gender, victimology, forensic psychology, policing, and criminology to consider and asses female involvement.

Laura Sjober and Cron Gentry's book highlights the political, gender, racial, and cultural dynamics of the contemporary world with women's increasing active participation in suicide bombings, hijacking airplanes, and taking hostages in such places as Palestine, Iraq, Afghanistan, Sri Lanka, Lebanon, and Chechnya.

Galit Ben-Israel points out the increasing impact of social media, which is contributing to the growing enthusiasm, attraction, and admiration of the Islamic State among the young Muslim women in Western Europe, ${ }^{24}$ a trend to be observed globally as a result of the spreading propaganda, becoming global and virtual phenomena and enticing more and more young Muslim girls in the West to become viral ISIS recruits and recruiters.

Kamila Zarychta-Romanowska primarily focused on various socio-cultural interactions, manipulating skills, and vulnerabilities of young women bounded by sisterhood strains, as well as the identity dilemma alongside other pull-push factors. The author highlights that the devotion to fighting jihad can be based on self-awareness and self-exclamation of their chosen lifestyle of a jihadi female fighter. $^{25}$

The Jihadi Game, described as a recruitment weapon by Miron Lakomy, more than ever requires us to consider the internet as a scene for hybrid threats

23 Women, Gender, and Terrorism, eds. L. Sjoberg, C. Gentry, Athens, GA 2011, p. 161; I. Vogel, I. Porter, M. Kebbell, "The roles of women in contemporary political and revolutionary conflict: A thematic model", Studies in Conflict and Terrorism 37, 2014, no. 1, pp. 91-114; "Reproducing a culture of martyrdom, the role of Palestinian women in discourse constructions, transmission, and legitimization", [in:] Motherhood and War: International Perspectives, eds. D. Cooper, C. Phelan, New York 2014; K. von Knop, "The female Jihad: Al Qaeda's women”, Studies in Conflict \& Terrorism 30, 2007, no. 5, pp. 397-414.

24 G.M. Ben-Israel, "Telling a story via Tumblr analytics: Europe's young Muslim female attraction to ISIS", International Annals of Criminology 56, 2018, special issue 1-2, pp. 55-78.

${ }^{25}$ K. Zarychta-Romanowska, "Foreign fighters as a threat to polish security and sovereignty", Revista facultății de drept oradea 2019, no. 1, pp. 95-122. 
of counterterrorism importance. ${ }^{26}$ The highlighted significance of the global medium - the internet and especially dark net - as a terrorism multiuse tool and a spectrum of propaganda, recruitment, and dissemination of messages of fear, terror, as well as the trade platform and crime scene, has an impact on female engagement and facilitation of terrorist involvement, as identified by UNODC, UN Women, OSCE, and the EU. Their attempt to curb online terrorist propaganda was described recently by K. Zarychta-Romanowska, Maciej Szostak, and Roman Romanowski. ${ }^{27}$

\section{Gender strategies in the security and development/ humanitarian response sectors}

The serious efforts and successes can be observed not only by applying already mentioned MenEngage initiatives, but also by the conglomerate of the exemplary standards OSCE sets regarding female equity. Not only does OSCE promote women's leadership and empower female professionals in conflict prevention management, peace processes, arms control, disarmament, and in the security sector, but also the organisation's overall strategy highlights the importance of gender equality and gender mainstreaming. By taking into account the different needs and perspectives of women and men when designing and implementing policies and programmes, the OSCE is tirelessly implementing its own Programme for Gender Issues, while developing operational tools, guidelines, and training materials to support OSCE staff members and stakeholders in integrating a gender perspective into their activities. Moreover, practical enforcing of the WPS agenda results in the creation and application of an OSCE Toolkit on Inclusion of Women and Effective Peace Processes (end of 2019). ${ }^{28}$ The Programme for Gender Issues works with OSCE field operations and institutions to help the participating states to prevent and combat violence against women, improve the protection and services for survivors of violence, and increase security for women and girls overall. The program not only collects and analyses data on the prevalence, forms, and consequences of violence against women and girls,

26 M. Lakomy, "Let's play a video game: Jihadi propaganda in the world of electronic entertainment", Studies in Conflict \& Terrorism 42, 2019, no. 4, pp. 383-40; idem, "Recruitment and incitement to violence in the Islamic State's online propaganda: Comparative analysis of Dabiq and Rumiyah", Studies in Conflict \& Terrorism 44, 2019, no. 7.

${ }^{27}$ K. Zarychta-Romanowska, M. Szostak, R. Romanowski "Cyber counter-terroryzm — innowacyjne perspektywy legislacyjno-policyjne polityki UE w perspektywie globalnego bezpieczeństwa", [in:] B. Wiśniewska-Paź, J. Stelmach, Bezpieczeństwo antyterrorystyczne budynków użyteczności publicznej. Dobre praktyki i rola wspótpracy cywilno-wojskowej, Warszawa 2020.

28 OSCE, Inclusion of Women and Effective Peace Processes: A Toolkit, 2019, https://www. osce.org/secretariat $/ 440735$. 
but also helps empower young female professionals in the fields of arms control, disarmament, and non-proliferation.

Moreover, as a unique and comprehensive setting, OSCE perceives the WPS agenda in a fully comprehensive manner. By supporting gender in economic and environmental security on field operations, women entrepreneurs are given access to resources and growing counseling networks providing training and legal advice on business-related matters. Meanwhile, the organization's OCEEA branch promotes women's skills in a wide array of sectors, from water diplomacy and green technologies to social economy, contributing to environmental security, the fight against crime and corruption, hence not only creating provisional solution, but also ensuring essential female involvement as a long-term goal.

When it comes to the European Union's gender security strategies, it is worth mentioning first of all that the European Union creates policies which include gender as a horizontal principle. The complex and evolving security threats the EU is facing, such as organized crime, terrorism, cyberviolence, and hybrid threats, have placed security high on the political agenda of both the previous (2014-2019) and current Commission (2019-2024). The set principle of equality between women and men is a core value of the EU, enshrined in treaties and the Charter of Fundamental Rights of the European Union. The observed dual approach is built on key actions to achieve gender equality combined with strengthening the integration of a gender perspective in all EU policies and major initiatives.

While gender mainstreaming tends to be implemented and integrated as a horizontal principle in all EU activities and indiscriminatory policies for all people to be able to live peacefully, enjoying equal rights and the same opportunities to realize their potential, the lack of EU gender advisor and other omissions seem remarkable. In the EU Parliament's own initiative report on gender equality in EU's foreign and security policy, among highlighted phrases are: "Gender equality as a guiding principle of the EU's external action," "A gender and diversity focus in the EU institutional culture at headquarters and delegations," "Prioritizing the protection and advancement of women's and girls' rights and their participation." The goal of the fifth SDG - to achieve gender equality and empower all women and girls worldwide - is presented as a tenet mainstreamed horizontally into the different EU policy fields, deeming the comprehensive policy of combating discrimination, notably against women and children, as evenly important.

The preventive mechanism against gender-based violence, political and social life exclusion, access to health, the protection of women and girls from violence, financial dependence, and discrimination shall be reinforced as the guidance for developing aid involvement of the European Union worldwide, but also within the institution, in order to fully eliminate all forms of discrimination and marginalization of women. Certainly the EU's Strategic Approach to WPS represents significant progress in terms of its engagement with the WPS agenda, which has 
to be followed by concrete commitments and actions to ensure women's and girls' involvement with protection and support mechanisms as a sine qua non condition to attain lasting peace and security both globally and within the European Union and its institutions. There still exists a category of "no efficient internal procedure against discrimination rights" for staff members. What is also needed is an EU gender advisor.

The EU Action Plan on WPS, while being an implementation of the commitments included in Resolution 1325 - if integrated into all EU efforts in support of sustainable peace, security, human rights, justice, and development in the context of EU cooperation with other regional and international organizations - can significantly reinforce the worldwide impact of the EU Global Strategy. But only if gender perspectives, equity, and female empowerment are fully integrated into all EU policies, including security, conflict prevention and resolution, as well as long-term peacebuilding and development. The EU security and law enforcement agencies should not only be fully operational and efficient, but also include the proportionate female representation as intelligence-led policing, big data, cultural profiling, standing corps, and management operatives. ${ }^{29}$

Establishing European global strategy and Gender Equality Strategy 2020 sets new internal and external security standards for women's safety. It shall therefore become fully implemented in various EU global security and policing initiatives inside and outside EU. This will contribute to efficient application of criminological, victimological, but essentially political and legal standards in European policing.

1. Adding violence against women to the list of EU crimes defined in the Treaty (so-called 'Eurocrimes') — European Arrest Warrant possible.

2. Action Plan on Gender Equality and Women's Empowerment in External Relations (GAP). The GAP II (2016-2020) focuses on ending violence against women and girls, promoting women's economic and social empowerment and ensuring the fulfilment of their human, political, and civil rights. GAP III will be launched in 2020 and will be closely linked to this strategy — the two strategic frameworks will thus be mutually reinforcing each other.

3. Prevention of harmful practices, including female genital mutilation, forced abortion or sterilization, early and forced marriage, and so-called 'honor-related violence' - including on stabilisation and external missions.

4. Adopting the Action Plan on Human Rights and Democracy (2020-2024); further implementing the EU Strategic Approach and Action Plan on Women, Peace and Security (2019-2024).

${ }^{29}$ Comprehensive analysis of origins and context of eu policing please compare: K. Zarychta-Romanowska, M. Szostak, "Frontex 3.0 - rewolucyjny czy rewelacyjny", Nowa Kodyfikacja Prawa Karnego 50, 2018, pp. 113-131; M. Szostak, K. Zarychta-Romanowska, "Policyjne strategie bezpieczeństwa granic unii europejskiej. Postulaty de lege lata i de lege ferenda", Przeglad Prawa i Administracji CXX (part 1), 2020, pp. 335-347. 
5. Spotlight Initiative, a joint EU-UN global program with $€ 500$ million EU funding to help eliminate all forms of violence against women and girls.

6. Launching the campaign \#WithHer in 2020, designed to challenge harmful gender norms and stereotypes which perpetuate violence against women worldwide.

All of these actions are more and more prioritised in the various EU external actions and WPS sectors. Female presence is indispensable in policing, at the borders, in the armed forces, in crisis management, and at the negotiating table. Otherwise, without inclusion, there is no safe societies nor sustainable peace.

\section{Bibliography}

Ben-Israel G.M., "Telling a story via Tumblr analytics: Europe's young Muslim female attraction to ISIS", International Annals of Criminology 56, 2018, special issue 1-2.

Fact Sheet: UN Security Council Resolution 2178 on Foreign Terrorist Fighters, https://www.jus tice.gov/file/344501/download.

Grott K., Szostak M., Incest Criminological Studies, Poznań 2013.

Knop K. von, “The female Jihad: Al Qaeda's women”, Studies in Conflict \& Terrorism 30, 2007, no. 5.

Lakomy M., "Let's play a video game: Jihadi propaganda in the world of electronic entertainment", Studies in Conflict \& Terrorism 42, 2019, no. 4.

Lakomy M., "Recruitment and incitement to violence in the Islamic State's online propaganda: Comparative analysis of Dabiq and Rumiyah", Studies in Conflict \& Terrorism 44, 2019, no. 7.

Loadenthal M, "Reproducing a culture of martyrdom, the role of Palestinian women in discourse constructions, transmission, and legitimization", [in:] Motherhood and War: International Perspectives, eds. D. Cooper, C. Phelan, New York 2014.

Motherhood and War: International perspectives, eds. D. Cooper, C. Phelan, New York 2014.

NATO, IMS Office of the Gender Advisor, https://www.nato.int/cps/en/natohq/topics 101372.htm.

NATO, Policy on preventing and responding to sexual exploitation and abuse, 20.11.2019, https:// www.nato.int/cps/en/natohq/official_texts_173038.htm.

OSCE, Inclusion of Women and Effective Peace Processes: A Toolkit, 2019, https://www.osce.org/ secretariat $/ 440735$.

OSCE, OSCE Men for Gender Equality, https://www.osce.org/secretariat/menengage.

PeaceWomen, Resolution Texts and Translations, https://www.peacewomen.org/resolutions-textsand-translations.

Report of the Secretary-General on women and peace and security (S/2015/716), https://reliefweb. $\mathrm{int} /$ report/world/report-secretary-general-women-and-peace-and-security-s2015716.

Sahrasad H., Tabrani D., Ridwan M., Puteh A., "Women and terrorism: A sketch on women and transnational terrorism in Southeast Asia and Indonesia", Konfrontasi: Jurnal Kultural, Ekonomi dan Perubahan Sosial 9, 2020.

Stability Policing: A Tool to Project Stability, eds. V. Stingo, M. Dziedzic, B. Barbu, Norfolk, VA 2000, https://www.act.nato.int/images/stories/media/doclibrary/stability_policing.pdf.

Szostak M., Controversial Cults: Various Approaches, Poznań 2013.

Szostak M., Desputable Religious Movements and Public Security, London 2013.

Szostak M., Sekty destrukcyjne. Studium metodologiczno-kryminalistyczne, Kraków 2001.

Szostak M., Wiśniewska-Paź B., Zarychta K., "Krymigracja, kryminalizacja migracji a abolicja nieregularnej migracji”, Studia Sociologica 2, 2019, no. 11. 
Szostak M., Wiśniewska-Paź B., Zarychta-Romanowska K., “Globalizacja nieregularnej migracji rozważania o wpływie międzynarodowego kryzysu migracyjnego i jego implikacjach", Transformacje XII, 2019.

Szostak M., Zarychta-Romanowska K., "Policyjne strategie bezpieczeństwa granic unii europejskiej. Postulaty de lege lata i de lege ferenda", Przeglad Prawa i Administracji 120 (part 1), 2020.

UN General Assembly, Plan of Action to Prevent Violent Extremism. Report of the Secretary-General, https://www.un.org/en/ga/search/view doc.asp?symbol=a/70/674.

UN Security Council, Resolution 1325, Women and peace and security, http://unscr.com/en/resolu tions/1325.

UN Security Council, Resolution 2396, Threats to international peace and security caused by terrorist acts, http://unscr.com/en/resolutions/2396.

Universal Declaration of Human Rights, https://www.un.org/en/about-us/universal-declaration-ofhuman-rights.

Vogel I., Porter I., Kebbell M., "The roles of women in contemporary political and revolutionary conflict: A thematic model", Studies in Conflict \& Terrorism 37, 2014, no. 1.

Women, Gender, and Terrorism, eds. L. Sjoberg, C. Gentry, Athens, GA 2011.

Zarychta-Romanowska K., "European border and coast guards agency: Irregular migration management and creation and application of EU immigration law", Revista Facultatii de Drept Oradea 2018 , no. 1 .

Zarychta-Romanowska K., "Foreign fighters as a threat to polish security and sovereignty", Revista facultății de drept oradea 2019, no. 1.

Zarychta-Romanowska K., Szostak M., "Frontex 3.0 - rewolucyjny czy rewelacyjny”, Nowa Kodyfikacja Prawa Karnego 50, 2018.

Zarychta-Romanowska K., Szostak M., Romanowski R., "Cyber counter-terroryzm — innowacyjne perspektywy legislacyjno-policyjne polityki UE w perspektywie globalnego bezpieczeństwa", [in:] B. Wiśniewska-Paź, J. Stelmach, Bezpieczeństwo antyterrorystyczne budynków użyteczności publicznej. Dobre praktyki i rola wspótpracy cywilno-wojskowej, Warszawa 2020.

\section{Internet sources}

https://www.unodc.org/unodc/en/data-and-analysis/html.

https://www.unodc.org/unodc/en/gender/index.html.

Radicalisation Awareness Network, European Commission, https://ec.europa.eu/home-affairs/whatwe-do/networks/radicalisation_awareness_network_en. 